\title{
An Evaluation of Cripps' Population-Tied Schemes
}

\author{
Kaiying Zhu \\ London School of Economic and Political Science, London WC2A 2AE, London, UK
}

\begin{abstract}
As the world population reaches 7.8 billion in 2020, humanity's ecological footprint has become one of major global concerns. In this essay, I will explain population-tied schemes for distributing costs to reduce the global ecological footprint as found in Cripps's paper and discuss the issues related to them. I shall argue that a universal population-tied scheme is not morally defensible at the current stage, while a 'tailored' population-tied scheme with modifications is morally defensible.

Keywords: Population-Tied Scheme; Population Policies; Value

The Ecological Footprint measures how much demand human consumption places on the biosphere, and population-tied schemes aim to distribute our environmental duties by assigning equal per capita ecological footprints to states, but this is tied to a fixed population level. Under such schemes, Cripps identifies two types of permissible population policy: 1. choice-providing policies - include education, gender equality and health care for women in order to offer them alternatives to having many children, and 2. soft incentive-changing policies - include public environmental campaigns and financial incentives for being a green citizen. Cripps argues that modifications of population-tied schemes are needed because they would penalize states if they fail to control the population using all effective measures. This includes coercive polices which are commonly believed to be impermissible because they violate basic human rights.
\end{abstract}

\section{Unmodified population-tied schemes are problematic}

\section{I agree with Cripps that unmodified population-tied schemes are problematic}

Cripps rightly points out that soft incentive-changing policies are possible only where choice providing policies are in place, thus we may end up penalizing states' failure to introduce impermissible population policies. Additionally, poor countries are often unable to support incentive-changing policies due to a lack of resources. In poor countries, uneducated women not only lack career opportunities, but also lack education about contraception or gender equality. Population-tied schemes may deprive jobless individuals of fundamental interests, asking them not to have many children is to ask them to give up their only hope, because in low-income countries the unemployed have no pensions and social welfare are not sufficient. It is harsh to stand on moral high grounds and demand the poor to have the same understanding and to make the same decisions as those who are well-educated and privileged. Räikkä argues that population policies are undesirable if people are 'forced' to make procreative decisions under unjust social factors. I think the arguments Cripps made also under unjust social factors, some adjustments which ensure social justice are needed before population-tied schemes can be justified. I shall return to Räikkä's point later.

\section{Population-tied schemes as measures to preserve our environment}

Some argue that population-tied schemes are ethically unacceptable because we should consider the instrumental value and intrinsic value of additional people. Ord claims that a mature population policy should not consider only the costs of having more people but also their instrumental and intrinsic values. Nevertheless, a mature policy would consider the cost and the worst possible outcome of having more people. The worst outcome is perhaps what Hardin identifies as a "no technical solution problem". We should not put our bet solely on technology as it is a gamble that may cost us our planet. Therefore, propositions of population-tied schemes should be taken seriously as one of the efficient measures to preserve our environment.

It is true that we cannot completely set aside the connection between the population and the ecological footprint. The top ten countries ranked by total ecological footprint correlates to $70 \%$ of the top ten most populous countries. However, according to the data collected by Global Footprint Network, ecological footprints not only correlate to population but also income levels. Take the year of 2016 for example, if we compare the data we see that low-income countries generally have small footprints whilst high-income countries have the highest ecological footprints. In 2016, the United States' population was 323 million while India's population was 1.3 billion, but the United States' total ecological footprint was twice as much as India's. Additionally, talk of our 
planet's carrying capacity often uses an implicit standard of life. If we look at ecological footprint per capita, the United States' gha per capita is 8.1 while India is 1.2 . Given a set number of gha, would we prefer a world with 5 billion people having the average living standard of the United States or 10billion people having the average living standard of India? It is crucial to clarify which standard we are inferring. To implement population-tied schemes in populous low-income countries seems like a selfish excuse used by the rich to impose on the poor to maintain the rich's life standard which requires significantly larger ecological footprint. It is unfair to accuse the poor of having many children and to equate them with the rich who over consume. To minimize total ecological footprint, the poor sacrifices more like their fundamental rights, while the rich pay much less of a price like small lifestyle changes.

To prevent disastrous environmental issues, the sum of the world's ecological footprint would need to be equal to the available biocapacity per person on the Earth, which is currently 1.7 gha according to research. This means that if the world population increases, the gha allocated to each person will decrease. Therefore, governments can either: A. control population or B. to decrease existing ecological footprint per capita ( $8.1 \mathrm{gha})$. I argue that modified population-tied schemes are morally defensible in countries which have high: 1. global hectare (gha), 2. population number, and 3. average income, with a clause prohibiting impermissible procreative policies. These three conditions should be treated as integral; no single one can be omitted. The first two conditions have been justified. In addition to the analysis in the previous paragraph, it is unreasonable "to expect the poorest states to do either the impossible or the impermissible". It would be unreasonable to apply population-tied schemes in countries which already have low gha or in underpopulated or in low-income countries. Nonetheless, this does not mean population growth in densely populated low-income countries can be ignored. Since "the world's rich owe an ever increasing ecological debt," it is the global elite's moral duty to assist densely populated developing countries to implement permissible population policies if population-tied schemes are to be justifiable in those countries. It is crucial to ensure that people's procreative decisions are not influenced by unjust social factors. In short, different policies are applicable to different societies. I believe modified population-tied schemes are morally defensible in countries which satisfy the three conditions above. Although one might object that this third condition seems unfair for the rich in developed countries, Rawls' difference principle can be used to defend our claim, which states that social and economic inequalities are permitted if they make the least advantaged better off.

\section{Changes in values and lifestyles}

I believe our primary concern will not be introducing population-tied schemes or controlling world populations in general, but to change our values which results in changing our lifestyles. From the data above we could see that many low in-income countries have low gha, though they have no choice due to poverty. Adding more people has two kinds of cost: I will call them the expensive cost and the environmental-friendly cost. We focus too much on the expensive cost - population control policies. People are unwilling to give up pursuing more expensive lifestyles, given that resources are finite putting pressure on policies to control populations. Rather, we should consider paying the environmental-friendly cost - everyone adopts a much greener lifestyle and reduces the environmental damage we cause so that we could have more people. Whether our planet will be able to provide for more people depends on technological limits and social limits such as certain cultural groups forbidden abortions and the rich are reluctant to adopt a more environmental-friendly lifestyle. Technological limits can be reduced by adding funds to incentivize projects while social limits can be lessened by educational campaigns and social reforms. Although Hardin's argument is plausible to a certain extent, a finite world can support only a finite population, but we do not know the maximum population yet. Fundamentally, our concern is to reduce ecological footprint not to control population, and population-tied schemes are only one of the means which can be used to achieve that aim.

\section{Conclusion}

I believe a universally applied population-tied scheme for distribution of the costs of reducing global ecological footprint is not morally defensible. However, it is never morally defensible because one day we may be able to reduce the gap between rich and poor, perhaps then, such population-tied schemes could be defensible. Or when we have overcome certain technological limits we will not need to impose population tied schemes anymore. I hope for a better, fairer world where population-tied schemes are unnecessary. Nevertheless, discussion of population-tied schemes is important as it is something we will have to address one way or another. Although population is not the only problem, it is dangerous to neglect. Therefore, I have argued that schemes which satisfy the three conditions are morally defensible. Implementation of such schemes can prevent "freedom in a commons brings ruin to all."

\section{References}

1 Hardin, Garrett. "The Tragedy of the Commons," Science 162, no. 3859 (13th December, 1968): 1243-1248. DOI: 10.1126/ science.162.3859.1243.

2 Hardin, Garrett. "Living on a Lifeboat," Bioscience 24, no. 10 (Oct 1974): 561-568.

3 Cripps, Elizabeth. "Population and Environment: The Impossible, the Impermissible, and the Imperative," in The Oxford Handbook of Environmental Ethics, edited by S.M. Gardiner and A. Thompson, Oxford: Oxford University Press, 2016. DOI: 10.1093/oxfordhb/9780199941339.013.34.

4 Global Footprint Network,2016.http://data.footprintnetwork.org/?ga=2.132872966.965564109.1587101578- 1062232488.1586752490\#/. Last accessed 18th April 2020.

5 Hardin, Garrett. "The Tragedy of the Commons," Science 162, no. 3859 (13th December, 1968): 1243-1248. DOI: 10.1126/ science.162.3859.1243. 
6 Hardin, Garrett. "Living on a Lifeboat,” Bioscience 24, no. 10 (Oct 1974): 561-568. https://www.garretthardinsociety.org/ articles_pdf/living_on_a_lifeboat.pdf.

7 Heyward, Clare. "A Growing Problem: Dealing with Population Increases in Climate Justice," Ethical Perspectives 19, no. 4 (2012): 703-732. http://www.ethical-perspectives.be/viewpic.php?LAN=E\&TABLE=EP\&ID=1435.

8 Parfit, Derek. Reasons and Persons, Oxford: Clarendon Press, 1984.

9 Räikkä, Juha. “Coercive Population Policies, Procreative Freedom, and Morality,” Philosophy \& Geography 4, no.1 (2001): 67-77. DOI: 10.1080/10903770123420.

10 Rawls, John. A Theory of Justice, revised edition, Cambridge, Mass.: The Belknap Press of Harvard University Press, 1999.

11 Rawls, John. Justice As Fairness: A Restatement, 2nd edition, edited by Erin. I. Kelly, Cambridge, Mass.: The Belknap Press of Harvard University Press, 2001.

12 Worldometers, Population of India and U.S.A, https://www.worldometers.info/world-population/india-population/ https:// www.worldometers.info/world-population/us-population/ Last accessed 18th April 2020.

13 World Population Policies Database, https://esa.un.org/PopPolicy/about_database.aspx Last accessed 18th April 2020. 